\title{
An Analysis of Students' Sociocultural Competence in Delivering Suggestion Speech Act
}

\author{
Melati, NyimasTriyana S \\ Faculty of Teacher Training and Education, Universitas Jambi, Jambi, Indonesia \\ melatijaya3108@gmail.com
}

\begin{abstract}
This paper is aimed at describing English students' competence at Universitas Jambi in performing speech act of giving suggestion as one of speech acts studied in English subject. Discourse Completion Test (DCT) is used as data collection method and the taxonomy of suggestion linguistic realization strategies by MartinezFlor (2005) is used as the framework for analyzing data. The framework divides suggestion strategies into three main categories, namely direct, conventionalized form, and indirect. The finding suggests that most students employ conventionalized form of delivering suggestion, while others tend to be more direct. Only a small number of them use impersonal and hint as indirect strategy in delivering suggestion. It seems that students do not use many variations when producing suggestion speech act. However, some of the data interestingly show some modification strategies to downgrade the imposition a suggestion might have. Finally, it is expected that this research can contribute to developing the teaching and assessing of students' sociocultural competence particularly at English Department, Universitas Jambi.
\end{abstract}

Keywords: Sociolinguistic competence, suggestion speech act

\section{INTRODUCTION}

When using a language, both in oral and written forms, language learners must consider the communicative ability to understand well. Being able to analyze the situation and then to produce appropriate and acceptable response will make two communication purposes be achieved, namely transactional and interpersonal purposes. Transactional purpose deals with messages contained in the utterance. Meanwhile interpersonal purpose tends to see how the message is conveyed in the utterance. Put simply, there is a wide range of choices from "Hi" until "How do you do?" along with various intentions of choosing one variety instead of others. In addition, according to Stockwell (2007), it is considerably easy for anyone to understand a wide variety of languages in terms of styles and registers, but it becomes questionable when they are asked to produce one. This happens not only in second language learning but also in the first language learning. Thus, as mentioned earlier, it seems important to be able to have good ability in communication skills.

However, in the process of learning or acquiring second language, there is so-called 'interlanguage' which generally can be defined as imperfect ability in producing sentence or utterance in target language. The language learners have not yet acquired the second language fully and their language behavior is interfered by the first language linguistic aspect.

A lot of research has addressed this phenomenon, particularly in the field of Interlanguage Pragmatic (ILP). A grammatically advanced learner may not know how to use language appropriately in different contexts due to insufficient ability of pragmatic/sociolinguistic competence. This is the area of interest, where there is a gap between what to expect and what is obtained.

The need of owning sociocultural competence in second language acquisition is considered to be crucial. As part of communicative competence, sociocultural competence is closely related to how to say something appropriately in specific speech context. Thus, foreign language learners are required to have this competence to avoid misunderstanding when having a conversation. Failure to meet what is expected may cause conversation breakdown among the parties involved. With regards to learning English in Indonesia, the context of learning is more academic, which is learning English for the sake of a test at the end of the lesson. Then, it affects the interaction and the lesson taught to students. Less attention is given to language use in everyday basis. It leads to incomprehensive ability of students in owning communicative competence.

Therefore, this research explores how far the students' awareness in using language. Particularly, it describes the linguistic realization in giving suggestion delivered by English Department students of University of Jambi. Suggestion is chosen among other speech acts because it is used frequently by students and lecturers in campus setting. In addition, there are still limited research addressing this issue at the English Department of University of Jambi. The finding is used as a basis for constructing plans for teaching cross cultural speech act realisation with the purpose of gaining the knowledge and skill for students to use language in various situation and of avoiding cultural misunderstanding when using second language.

Communicative competence (Fauziati, 2014) has been one of theories used in learning English in Indonesia. It is believed by mastering this competence; one should be able to communicate appropriately. Communicative competence covers five areas, namely discourse competence, strategic competence, linguistic competence, actional competence, and socio cultural competence. 
Discourse competence is related to one's ability in making coherence and cohesion, so the utterance or the sentence produced has unity. Strategic competence deals with the ability in handling communication. For example, in a conversation, proper strategy is needed to start or to end the exchange. It may lead to communication breakdown if this fails to be met. Meanwhile the linguistic competence, as the name suggests, is more on the mastery of vocabulary and grammar. Then, actional competence is about the ability in comprehending and producing the communicative intention of an illocutionary force by using proper linguistic form. The sociocultural competence is highly required to produce appropriate utterance/sentence based on different social contexts. These two competences are closely related to pragmatic aspect in linguistic. This present study intends to focus more on the last two competences because a language learner tends to use the pragmatic value of his first language and use it when s/he speaks using target language.

The speech act under study is suggestion. It is a directive speech act which means that the speaker wants the hearer does something as what is intended by the speaker. The difference between suggestion and request lies on the benefit of the imposition contained in the speech act. When a speaker requests something to be done by the hearer, the exclusive benefit is only for the speaker. Meanwhile, when a speaker suggests something to be done by the hearer, the benefit tends to be the hearer's. The proper strategy is required because suggestion head act is also included as Face Threatening Act (Bowe \& Martin, 2007). The following is the taxonomy of delivering suggestion according to Martinez-Flor (2005). The analysis also includes modification strategy as proposed by Torsbog (1995) to obtain depiction how students modify their suggestion utterances.

Table 1. Taxonomy of Suggestion Linguistic Realization Strategies (Martinez-Flor, 2005)

\begin{tabular}{|c|c|c|}
\hline Type & Strategy & Examples \\
\hline \multirow[t]{4}{*}{ Direct } & Performative Verb & $\begin{array}{l}\text { I suggest that you ... } \\
\text { I advise you to ... } \\
\text { I recommend that you ... }\end{array}$ \\
\hline & Noun Suggestions & My suggestion would be ... \\
\hline & Imperative & Try using ... \\
\hline & Negative Imperative & Don't try to ... \\
\hline \multirow[t]{5}{*}{ Conventionalized Forms } & $\begin{array}{l}\text { Specific formulae } \\
\text { (interrogative form) }\end{array}$ & $\begin{array}{l}\text { Why don't you ... } \\
\text { How about ...? } \\
\text { What about ...? } \\
\text { Have you thought about ...? }\end{array}$ \\
\hline & Possibility/Probability & $\begin{array}{l}\text { You can } \ldots \\
\text { You could } \ldots \\
\text { You may } \ldots \\
\text { You might } \ldots \\
\end{array}$ \\
\hline & Should & You should ... \\
\hline & Need & You need to ... \\
\hline & Conditional & If I were you, I would ... \\
\hline \multirow[t]{2}{*}{ Indirect } & Impersonal & $\begin{array}{l}\text { One thing (that you can do) would be ... } \\
\text { Here"es one possibility ... } \\
\text { There are a number of options that you ... } \\
\text { It would be helpful if you ... } \\
\text { It might be better to ... } \\
\text { A good idea would be ... } \\
\text { It would be nice if ... }\end{array}$ \\
\hline & Hints & I've heard that ... \\
\hline
\end{tabular}


Table 2. External Modification (Torsbog, 1995)

\begin{tabular}{lll}
\hline $\begin{array}{l}\text { Strategies } \\
\text { Name }\end{array}$ & Function & Examples \\
\hline Grounder & $\begin{array}{l}\text { Provides reasons, explanations, and } \\
\text { justifications for the suggestions }\end{array}$ & $\begin{array}{l}\text { Erm, unfortunately, I really don } \\
\text { understand this topic here... }\end{array}$ \\
\hline Preparator & $\begin{array}{l}\text { Short utterance that intends to prepare the } \\
\text { hearer for the suggestions }\end{array}$ & May I give you a suggestion? \\
\hline $\begin{array}{l}\text { Imposition } \\
\text { Minimizer }\end{array}$ & $\begin{array}{l}\text { Reduces the imposition placed on the } \\
\text { hearer by the suggestion offered }\end{array}$ & $\begin{array}{l}\text { I will return them immediately, the } \\
\text { next day... }\end{array}$ \\
\hline Disarmer & $\begin{array}{l}\text { Remove any potential objection the hearer } \\
\text { might raise }\end{array}$ & $\begin{array}{l}\text { I am not trying to be smart, but I just } \\
\text { need you to ... }\end{array}$ \\
\hline
\end{tabular}

Table 3. Internal Modifcation (Torsbog, 1995)

\begin{tabular}{lll}
\hline $\begin{array}{l}\text { Strategies } \\
\text { Name }\end{array}$ & Function & Examples \\
\hline $\begin{array}{l}\text { Conditional } \\
\text { Clause }\end{array}$ & $\begin{array}{l}\text { Employed by speakers to distance themselves } \\
\text { from the suggestion }\end{array}$ & $\begin{array}{l}\text { I would like to ask, if you could } \\
\text { maybe to do this firsthand? }\end{array}$ \\
\hline Interrogative & $\begin{array}{l}\text { Used to downtone the impact of the } \\
\text { suggestion by appealing to the hearer"s } \\
\text { consent }\end{array}$ & $\begin{array}{l}\text { Could you point me the clear } \\
\text { solutions for this problem? }\end{array}$ \\
\hline Negation & $\begin{array}{l}\text { Employed by speakers to downtone the } \\
\text { force of the suggestion by indicating their } \\
\text { lowered expectations of the suggestion } \\
\text { being given }\end{array}$ & $\begin{array}{l}\text { You couldn"t repeat what you } \\
\text { have explained please? }\end{array}$ \\
\hline Appealer & $\begin{array}{l}\text { Used by the speakers to appeal the hearer"s } \\
\text { benevolent understanding }\end{array}$ & $\begin{array}{l}\text { You know, you shouldn"t drink too } \\
\text { much alcohol }\end{array}$ \\
\hline Hedge & $\begin{array}{l}\text { Used to indicate tentativeness, possibility and } \\
\text { lack of precision }\end{array}$ & $\begin{array}{l}\text { Is it possible if we can arrange a } \\
\text { meeting during the holidays } \\
\text { somehow? }\end{array}$ \\
\hline $\begin{array}{l}\text { Politeness } \\
\text { marker }\end{array}$ & $\begin{array}{l}\text { Employed by the speakers to bid for their } \\
\text { hearersec cooperation }\end{array}$ & $\begin{array}{l}\text { Could you give more explanation, } \\
\text { please? }\end{array}$ \\
\hline Subjectivizer & $\begin{array}{l}\text { Explicitly expressed by the speaker to show his } \\
\text { or her subjective opinion to the state of affairs } \\
\text { referred to in the proposition }\end{array}$ & $\begin{array}{l}\text { Ibelieve morality is important than } \\
\text { appearance... }\end{array}$ \\
\hline Understater & $\begin{array}{l}\text { Adverbial modifiers used to underrepresent the } \\
\text { state of affairs referred to in the proposition }\end{array}$ & $\begin{array}{l}\text { That might be a bit better for us } \\
\text { than the junk food... }\end{array}$ \\
\hline
\end{tabular}

There are number of studies discuss the sociocultural (pragmatic) competence in the second language acquisition/learning. Mostly, the studies suggest that language learners often fail to perform as what is expected in the target language. It also happens even for the native speaker. As mentioned earlier, people find it more difficult to produce the style/register compared to the comprehension of the style/register. This study tries to explore the gap by describing the suggestion formulation so the English learners, particularly at English Department of University of Jambi, may be informed about their sociocultural competence.

\section{METHOD}

This was a descriptive qualitative research which aimed at describing linguistic variation of students' utterance in delivering suggestion. The data were collected by using Discourse Completion Test (DCT) instrument. The DCT's situations were set based on three factors that affect one's choice in his language behavior, namely D (Distance), P (Power), and $\mathrm{R}$ (imposition). However, $\mathrm{R}$ factor was not clearly stated in the DCT since it is better that the participants themselves who determine the impact of the imposition contained in their 
suggestion. Thus, they would choose the appropriate choice from their language repertoire.

As the participants, there were 10 students of English Department becoming the respondents of this research. They were selected on the basis that they were $6^{\text {th }}$ semester students who had studied linguistics and had experienced sufficient learning duration in their English study.

The participants were given 12 situations and were asked to give responses based on the situations. Their responses were recorded. This study used oral DCT because the data elicited from the participants will be more natural than of those of the written DCT. In written DCT, the participants have more time to think of the answers compared to oral DCT which was expected to be more spontaneous, as what happens in ordinary conversation (Byon, 2006).

The data obtained from the recording activity were then transcribed. The data were coded and analysed by using the taxonomy of giving suggestion (Martinez-Flor, 2005) and modification strategies (Torsbog, 1995). There are three main categories in delivering suggestion, namely direct, conventionalised, and indirect forms and there are two main types of modification strategies, namely external and internal modification. The analysis for suggestion focused on the suggestion head act, for example, "why don't you...", "I would suggest...", "it is better for you...", etc. Also, the analysis included the modification strategies contained in the suggestion (Torsbog, 1995) in order to have deeper description of the data.

\section{RESULT \& DISCUSSION}

In order to analyze the linguistic realization of students' suggestion, the author firstly presents the table below to show the general overview of the suggestion.

Table 4. Type of Suggestion Strategies

\begin{tabular}{lcccccc}
\hline \multicolumn{1}{c}{ Social Variables } & & & & & & \\
Suggestion type & $+\mathrm{P}+\mathrm{D}$ & $+\mathrm{P}-\mathrm{D}$ & $=\mathrm{P}+\mathrm{D}$ & $=\mathrm{P}-\mathrm{D}$ & $-\mathrm{P}+\mathrm{D}$ & $-\mathrm{P}-\mathrm{D}$ \\
\hline Direct & 7 & 1 & 5 & 5 & 1 & 5 \\
\hline Conventionalized & 9 & 16 & 7 & 11 & 11 & 13 \\
\hline Indirect & - & 3 & 6 & 3 & 5 & 1 \\
\hline
\end{tabular}

Generally, the results demonstrated in table 2 show that most students employ the conventionalized form more than the other. The conventionalized phrases like, "why don't you...", "You should...", "You need to..." contribute the most of the suggestion produced by the students. In all constellations, students prefer to use these expressions. Only when the situation where the speaker and hearer are having the same power and there is social distance between them, the strategies used are evenly distributed among direct, conventionalized, and indirect forms. There are two possible reasons that may account for the choice. Firstly, avoiding direct suggestion will surely reduce the imposition of the suggestion. Moreover, avoiding indirect form of suggestion will reduce the likelihood of misunderstanding the suggestion. The participants want themselves to be straight but still somehow 'respect' the personal territories of the hearers. According to Martinez-Flor (2005), 'conventionalized form of suggestion realization still allows the hearers to understand the speaker's intention behind the suggestion'. The imposition is indeed contained in the utterance but it is forceless if compared to direct form. The following are examples of conventionalized suggestion produced by students:

“why don't you ask your teacher or ask me ...”.

"I think you'd better buy the book in that book store."

"I think you can start eating organic food ..."
The result also indicates the lack of variety of suggestion head acts produced by the students. The repeated use of those conventionalized phrases gives a depiction that students need to be exposed more to language varieties and how they are used in terms of delivering suggestion. Students still rely heavily on the ordinary suggestion like listed previously. Surely, it is not a mistake, but showing more varieties will show a better competence of the students.

In addition, the uses of direct and indirect suggestion seem less favored by the students. In fact, the chance of both direct and indirect forms to simultaneously occur may actually increase if the hearers consider further to whom they speak. Direct suggestion, though it is regarded as very direct, still somehow can be used in informal or formal suggestion. The phrase "My suggestion would be..." actually fits to formal situation, but it is not used by the students. It also happens for indirect suggestion. There are students who employ impersonal and hints as their suggestion strategy. Delivering the suggestion indirectly requires a high stake of competency. The speakers want the hearers to take it as the suggestion, and at the same time, they want the suggestion less imposing. For example, in the situation when a student wants to give suggestion to his lecturer about smoking, the student might use indirect strategy. The use of impersonal phrase like "it is better for you if ..." is not used 
very often as what is expected to be used. The following are data samples for direct and indirect suggestions:

"I would like to suggest you have to study hard from now" (direct performative)

"Come on guys be quite for moment, please." ( direct imperative)

"I don't think it is good for you to continue smoking." (indirect impersonal)

"It would be better for you if youstop playing game and start to learn for your national exam soon." (indirectimpersonal)

Interestingly, almost all data show the modification strategy of giving suggestion in all constellations. Some of the students give justification for the suggestion by explaining the situation first or after the suggestion (Torsborg, 1995). They give the background for the suggestion, like "Guys, I found that you two have low motivation in study, so I would like to suggest you ...”. Others use 'please' as lexical down graders when they say imperative direct suggestion, or "I think" to reduce the imposition. Some others use negative question to down tone the force of suggestion "can't you ..." to indicate the impossibility of the hearer to accomplish the suggestion. These modifications are employed to reduce the FTA of the suggestion head act. This language behavior is also true for native Indonesian speakers who tend to explain the situation at the first hand, then followed by the intention. This is called as circular discourse (Kaplan in Bowe \& Martin, 2005). However, only these four types of modification are commonly employed by the participants.

Table 5. Modification strategies

\begin{tabular}{|c|c|c|}
\hline Name & Function & Data \\
\hline Grounder & $\begin{array}{l}\text { Provides reasons, explanations, and } \\
\text { justifications for the suggestions }\end{array}$ & $\begin{array}{l}\text { "I found that you two have low } \\
\text { motivation in study, so I would like } \\
\text { to suggest you ...". }\end{array}$ \\
\hline Negation & $\begin{array}{l}\text { Employed by speakers to downtone the force of } \\
\text { the suggestion by indicating their lowered } \\
\text { expectations of the suggestion being given }\end{array}$ & $\begin{array}{l}\text { Can't you stop playing games } \\
\text { because you'll face national exam } \\
\text { soon so you need to study hard from } \\
\text { now on }\end{array}$ \\
\hline Politeness & $\begin{array}{l}\text { Employed by the speakers to bid for their } \\
\text { hearers }{ }^{\text {ee }} \text { cooperation }\end{array}$ & $\begin{array}{l}\text { come on guys, be quite for moment, } \\
\text { please. }\end{array}$ \\
\hline Subjectivizer & $\begin{array}{l}\text { Explicitly expressed by the speaker to show his } \\
\text { or her subjective opinion to the state of affairs } \\
\text { referred to in the proposition }\end{array}$ & $\begin{array}{l}\text { I think you should turn off the music } \\
\text { because I'm studying in the next } \\
\text { room. }\end{array}$ \\
\hline
\end{tabular}

This study clearly shows the need of explicit instruction of the socio cultural and actional competence. Students need to be exposed to various situations, though it is not a real one that enables them to use the language communicatively. There are studies that have proposed this idea. For example, studies that have been conducted by Aufa (2014) and Byon (2006). Both studies indicate the need of explicit cross cultural pragmatic teaching in order to raise the awareness of different utterance due to different situation. They specifically adressed the effectiveness of DCT as instrument for explicit pragmatic teaching. Another example is study by Soler (2008) where she analyses two perspectives in learning pragmatic, namely cognitive and socially oriented approach. All of these three studies strongly indicate the need for cross cultural pragmatic teaching in order to have a good command of second language competence.
According to Kasper (1997) there are two main stages for pragmatic teaching, namely awareness-raising activities and opportunities for communicative practice. Awareness raising activities may involve the identification of who are participating in the conversation, pinpoint the language variation in delivering certain speech act, and choose the appropriate language variation based on available choice (exercise). While for opportunities for communicative practice, after the students complete the first stage, they can be put in an artificial situation so that they can practice their knowledge about pragmatic. By describing the students' competence, it gives reliable information to the autho that the two parts of pragmatic teaching proposed by Kasper is still lack and therefore are needed to be accomplished. Thus, foreign language teaching strategies are required to answer the challenge. Further task is to design comprehensive plans and materials for teaching cross cultural speech act realisation with 
the purpose of gaining the knowledge and skill for students to use language in various situation and of avoiding cultural misunderstanding when using second language. Lastly, one thing to be noted is that this pragmatic teaching, just like other skills like listening or reading, proceeds in a non-linear fashion (Salemi, Rabiee, Ketabi: 2012). The students might forget what has been taught to them. Providing them with continual chance will allow them to get the benefit of their language.

\section{CONCLUSION}

To sum up, this research is aimed at describing the linguistic realization of delivering suggestion speech act. Through DCT, the finding shows that most of the students employ conventionalized form of suggestion, which means there is a lack of variation in their language repertoire. In addition, finding also shows their ability in using several strategies to downgrade the imposition of the suggestion they have delivered. However, the modification variation used by students is quite limited and thus, lack of variety. This clearly shows that the students need more systematic practice in delivering suggestion so that they will be able to produce a better suggestion later. This is also true for other pragmatic teaching, so at the end of English lesson, students' will have more comprehensive ability in terms of communicative competence.

\section{REFERENCES}

Aufa, F. (2014). The use of discourse completion task (DCT) as explicit instruction on Indonesian EFL learners' production of suggestion act. International Journal on Studies in English Language and Literature (IJSELL), 2(6), 1-10.

Bowe, H., \& Martin, K. (2007). Communication across cultures: Mutual understanding in a global world. Australia: Cambridge University Press.

Byon, A. S. (2006). Developing KFL students' pragmatic awareness of Korean speech act: The use of discourse completion task. Language Awareness, 15(4), 244-263.

Dornyei, Z. (2007). Research method in applied linguistics. Oxford: Oxford University Press.

Fauziati, E. (2014). Modul Pelatihan Profesional Guru. Konsorsium Sertifikasi Guru

Kasper, G. (1997). Can pragmatic competence be taught? Honolulu: University of Hawai'i, Second Language Teaching \& Curriculum Center. Retrieved: from http://www.nflrc.hawaii.edu/NetWorks/NW06/

Martinez-Flor, A. (2005). A theoretical review of the speech act of suggesting: Towards a taxonomy for its use in FLT. Revista Alicantina de Estudios Ingleses 18(1), 167-187.

Salemi, A., Rabiee, M., \& Ketabi, S. (2012) The Effects of Explicit/Implicit Instruction and Feedback on the Development of Persian EFL Learners' Pragmatic Competence in Suggestion Structures. Journal of Language Teaching and Research, 3 (1), 188-199.
Soler, A. E. (2008). Investigating pragmatic language learning in Foreign Language Classroom. IRAL, Internasional Review of Applied Linguistics in Language Teaching, 46 (3), 173195.

Stockwell, P. (2002). Sociolinguistics: A resource book for students.London: Routledge.

Torsborg, A. (1995). Interlanguage Pragmatics: Request, Complaints, and Apologies. Berlin: Mouton de Gruyter 